Journal of Systems Science and Information

June, 2015, Vol. 3, No. 3, pp. 214-233

DOI: $10.1515 /$ JSSI-2015-0214

\title{
The Estimate of Capital Services by Sector in China
}

\author{
Wei XI \\ Institute of National Accounts, Beijing Normal University, Beijing 100875, China \\ E-mail:xiwei@bnu.edu.cn \\ Jun XU \\ Institute of National Accounts, Beijing Normal University, Beijing 100875, China
}

\begin{abstract}
Measuring the contribution of capital to productivity is always an important issue in economics. With the concept of capital service introduced in SNA2008, there are some changes in capital accounting itself. Particularly, R\&D expenditure has been recognized as part of capital formation for the first time in SNA2008. This part new capital formation changes the size of GDP. It has a profound impact on capital accounting. In this paper, the hyperbolic age-efficiency profile model is applied to measure the capital input of 86 sectors in China from 2002 to 2012. Endogenous rate of return and exogenous rate of return are used respectively to measure six fixed assets capital service index including $R \& D$ assets. Meanwhile, the implement of the sensitivity analysis for different assets and rates of return is used to identify the key factors that can affect the measurement of capital services. Moreover, this paper can also provide data and literature reference for researches on quantifying the capital's contribution to economic growth.
\end{abstract}

Keywords capital service; sector; productive capital stock; sensitivity analysis

\section{Introduction}

Capital is not only the most important part of national wealth, but also the prerequisite and foundation of national economic operation. Thus, the measurement of capital's contribution to production has been an important proposition in economics. What's more, the capital input is the necessary basic information in the empirical analysis of economic growth, total factor productivity and capital return. From the capital theory of Karl Marx to Cambridge Controversies $^{1}$, economists have been arguing about the definition and the measurement method of capital input for a long time.

In macroeconomics, for a long time, researchers used "durable goods stock" to define and measure capital, such as Jorgenson ${ }^{[1]}$, Jorgenson and Griliches's ${ }^{[2]}$ growth model, Hall and Jorgenson's ${ }^{[3]}$ construction of capital accounting framework, and Hulten and Wykoff's ${ }^{[4,5]}$ estimation of the capital depreciation rate. Later, many economists realized that it is the services

\footnotetext{
${ }^{1}$ The Cambridge Controversies refers to the theoretical divergences of neoclassical synthesis school and new Cambridge school in capital and income distribution from 1950s to 1970s. The debate once focused on the aggregation of heterogeneous capital goods in the aggregate production function.

This paper is supported by "the Fundamental Research Funds for the Central Universities (SKZZY2013004)", and "the National Social Science Fund Project(12CYJ004)".
} 
flow of capital, rather than the capital stock, which determines output of production. Namely, the capital input should be the capital services provided by capital goods within a certain period. Therefore, the chapter of capital service is specially introduced into the latest revision of system of national accounts (SNA, 2008) ${ }^{[6]}$ to present the accounting and recording of the capital input as flow in the production process. Related theories and methods come from the OECD Measuring Capital Manual and Measuring Productivity Manual ${ }^{[7,8]}$.

Then many scholars began to do empirical research based on the capital flow framework. For example, Oulton and Srinivasan ${ }^{[9]}$ built an empirical analysis framework of capital flow accounting; Schreyer ${ }^{[10]}$ measured the service flow of various physical capital including ICT in Australia, Canada, France, German, Italy, Japan, England and America from 1980 to 2001; Erumban ${ }^{[11]}$ compared the difference between European Union and America in the capital rental price, rates of return and capital productivity; Wallis ${ }^{[12]}$ estimated the capital services in England from 1950 to 2006. Inklaar ${ }^{[13]}$ found the choice of return rate had a significant influence on the measurement results in the empirical estimation of the capital services in America from 1977 to 2005.

The estimation of the contribution of research and development (R\&D) to productivity and growth is facing the same problem. Researchers used the present and lagged input of $R \& D$ expenditure as the innovation investment in initial empirical research. With much more knowledge of the capital feature of $R \& D$, researchers were beginning to estimate the knowledge production function using $R \& D$ capital stock as a variable. Since $R \& D$ is recognized as fixed capital included in the economic output in the latest version of SNA, we have to re-estimate the newly-formed capital with methods of flow accounting instead of stock accounting.

Currently, China only has the stock-level R\&D capital accounting since R\&D accounted as capital for a short time. When $\mathrm{Wu}^{[14]}$ studied the productivity of industrial sectors, he used Chinese large and medium-sized industrial enterprises' panel data to estimate the industrial R\&D capital stock; Wang ${ }^{[15]}$ estimated 28 Chinese manufacturing industries' R\&D capital stock from 1998 to 2005; Xiao and Xie ${ }^{[16]}$ estimated the R\&D capital stock of China's 31 provinces during 2000 to 2006 and explored the spatial distribution features; and Wang ${ }^{[17]}$ based on the U.S. R\&D satellite account, introduced and analyzed the R\&D capital stock estimation methods of BEA. Overall, these studies are limited to the stock-level of R\&D and neglect the flow-level, such as R\&D capital services.

On the topic of capital services accounting, China already has the fixed assets studies, but the R\&D assets has not been involved. Sun and Ren ${ }^{[18]}$ first reviewed the related theory of capital services and estimated the total factor productivity of China. Subsequently, Sun and Ren $^{[19]}$ estimated the capital services index in China from 1981 to 2000 on the industry level. Due to the infinite geometric depreciation model that is different from the actual situation, $\mathrm{Cai}^{[20]}$ first applied a hyperbolic function estimating capital services index in China from 1978 to 2007. Cao and Qin ${ }^{[21]}$ estimated the capital services index of China from 1978 to 2010; compared to the former research, their studies improve on the technical details such as the selection of depreciation rate. However, the calculation results that the productive capital stock is less than the wealth capital stock are contrary to the basic theory of capital services measurement. 
In summary, the capital services research of China currently has problems such as limited perspectives and inadequate systematization. In addition, R\&D has been considered one of the fixed assets in the international standards accounting system, the measurement of R\&D capital services in China is still empty. Therefore, this paper uses the hyperbolic age-efficiency profile to estimate the capital input of 86 sectors in China from 2002 to 2012, and calculates the capital services index of six fixed assets including R\&D. Furthermore, this paper analyzes the sensitivity of different capital types and return rates and tries to find the key factor in capital services measurement.

\section{The Measurement Framework of Sector Capital Services}

\subsection{The Method of Estimating Capital Services}

The contribution of various factors in production is reflected in the value-added; labor's contribution to production is regarded as the compensation of employees and capital's contribution to production is regarded as capital services. In the income accounting, value-added also includes the consumption of fixed capital and operating surplus, except for the compensation of employees. When all of the capital can be adequately considered, the sum of these two parts (consumption of fixed capital and operating surplus) is exactly the capital services itself.

\subsubsection{Rental Price and User Costs}

For some certain asset used in production, capital service as the flow of productivity covers all its service life. In a perfect market, user costs equal the rental price of capital goods. In fact, many assets are for self-use and we cannot observe the rental price of such assets in an imperfect market. So we use user costs to distinguish it.

$$
f_{t}^{i}=q_{t}^{i} \times\left(r_{t}^{i}+d_{t}^{i}\right)-\left(q_{t}^{i}-q_{t-1}^{i}\right)
$$

Equation (1) is the expression of user costs derived from the asset pricing model. In the equation, $q_{t}^{i}$ denotes the purchase price of assets in year $t$ and $q_{t-1}^{i}$ denotes the price in year $t-1, r$ indicates the rate of return, and $d$ denotes the depreciation rate. Therefore, user cost is composed of three parts: Capital return, capital consumption and capital value changes brought by inflation.

\subsubsection{Unit User Costs and Productive Capital Stock}

Capital services is a quantitative variable as well as a value variable. As a quantitative variable, it represents the capacity or efficiency that a certain asset can supply in production; as a value variable, unit user cost is just the unit price of that abstract productivity. As a quantitative variable, capital services is difficult to measure directly and it is usually recognized as a proportion of productive capital stock. Hence, for a single asset, the productive capital stock index varying over time is the capital service index.

$$
K_{t}^{p}=K_{t}^{p}(1-\delta)+I_{t}=\sum_{\tau=1}^{\infty} h_{\tau}^{i} I_{t-\tau}
$$


In Equation (2), $K_{t}^{p}$ indicates the productive capital stock and $h_{t}^{i}$ denotes the comprehensive efficiency considering the retirement distribution. The principle of measuring productive capital stock is consistent with PIM (perpetual inventory method). Notably, means efficiency loss other than the decline of price.

\subsubsection{Productive Capital Stock and Age-Efficiency Profile}

Not only the decline in asset productivity but also the decline of asset price presents the change in investment over time. The former is displayed with age-efficiency profile while the latter is displayed with age-price profile. Furthermore, productive capital stock corresponds to age-efficiency profile and wealth capital stock corresponds to age-price profile. The specific form of age-efficiency profile is an empirical question itself, but the hyperbolic curve model is an ideal choice for most fixed assets including R\&D.

$$
g_{s}^{i}=\frac{T^{i}-s}{T^{i}-b^{i} s}
$$

Equation (3) is the functional form of the hyperbolic curve model of age-efficiency profile. And $i$ denotes asset type; $T_{i}$ indicates the maximum service life of the asset $i$; $s$ indicates the age of the asset. Since it is impossible for the assets to retire at the same time, $T_{i}$ is a random variable following retirement function distribution. Moreover, $b$ denotes an efficiency reduction parameter. According to the service lives of different assets, $b$ equals 0.7 for basic research, 0.6 for applied research and 0.5 for experimental development ${ }^{2}$.

\subsubsection{Aggregation of Capital Services}

When aggregating the total capital services from different types of assets, we need to consider the selection of the index formula and aggregation weights. It is appropriate to use chained superlative index, among which we choose the Tornqvist index. On the other hand, the aggregation weight of each type of asset is the proportion of its capital return within the gross capital return, and capital return is the product of user cost and capital service.

$$
\begin{aligned}
& \prod_{i}\left(\frac{K_{i, t}^{P}}{K_{i, t-1}^{P}}\right)^{w_{i}} \\
& w_{i, t}=\frac{f_{i, t} K_{i, t}^{P}}{\sum_{i} f_{i, t} K_{i, t}^{P}}
\end{aligned}
$$

Equation (4) is the gross capital service index and $w_{i}$ is the aggregation weight. The calculation of $w_{i}$ is expressed in Equation (5).

\subsection{Other Issues on the Measurement Capital Services by Sector}

\subsubsection{Accounting Scope of R\&D Capital}

According to SNA2008, assets which generate capital services are those non-financial assets contributing to the production process. Specifically, they include fixed assets, inventories,

\footnotetext{
${ }^{2}$ Generally, the longer the service life is, the higher the value of $b$. The Australian Bureau of Statistics (2000) sets the $b$ value of a database product 0.5 .
} 
natural resources and contracts, leases and licenses used in production. As a new part of fixed capital formation, R\&D expenses also produce capital services. However, not all R\&D expenses can be classified as capital; the necessary condition is that the expenditure can bring economic benefits to the owner. According to the statistical caliber of "Frascati Manual", R\&D expenses are distributed into three types: Basic research, applied research and experimental development. If taking market products as the sign of economic benefits, then basic research is obviously distant from the concept of capital, applied research follows, and experimental development is the most likely to be put into market production. Although most of the basic research is similar to public products whose expected returns are indirect, its economic benefits will be embedded in the subsequent products of applied research and experimental development, rather than consumed completely. Therefore, this paper considers that the distinction between basic research and the other two R\&D expenses is mainly reflected in capitalization rates and sets the capitalization rate of basic research as $50 \%$ and of applied research as $80 \%$, with experimental development for all transformation.

\subsubsection{The Choices of Return Rate}

There are two kinds of rate of return: Endogenous rate of return and exogenous rate of return. When taking full account of all the assets' contribution to productivity, capital services are the sum of fixed-capital consumption and operating surplus. Thus, endogenous rate of return can be calculated according to the equation as follows:

$$
\sum_{i} f_{t}^{i} K_{t}^{i}=\sum_{i} q_{t}^{i} \times\left(r_{t}^{i}+d_{t}^{i}-\frac{q_{t}^{i}-q_{t-1}^{i}}{q_{t}^{i}}\right) \times K_{t}^{i}
$$

The left side of the equation is the sum of capital return, which can be obtained from production account. And $r$ coming from Equation (6) is the endogenous rate of return. While exogenous rate of return is directly assigned to be equal to some specific interest rate, without regard to the equilibrium relation of accounting. No final conclusion has yet been reached on which rate of return is better. For the endogenous rate of return, all the assets should be involved in calculating, which means all the assets are observable, otherwise there will be a biased result. Under the premise that $R \& D$ activities is included in the capital accounting scope, this paper will use those two methods to measure China's sector capital services, and compare their influences on the calculation results by sensitivity analysis. For the exogenous rate of return, referring to the rates of return of corporate bonds and the interest rates of bank medium-term and long-term loans, we assign $5 \%$ to the return rate of fixed assets.

\section{The Empirical Analysis of Capital Services by Sector}

\subsection{Data}

According to the measurement framework previously discussed, the parameters required for estimating China's capital services by sector mainly include: The annual data of investments at the categorized assets level, price index, the base year's capital stock, service lives for different assets and depreciation rates. 


\subsubsection{Investment Data}

On investment flows, statistic material have two groups of data, fixed capital formation data and fixed assets investment data. Since the whole society fixed assets investment includes the old equipment and old buildings acquisition costs, which may repeat in the calculation, and the whole society fixed assets investment do not include urban and rural non-farmers' fixed assets investment projects under 0.5 million yuan as well as mineral exploration, computer software and other costs of intangible assets ${ }^{[2]}$, so the OECD recommends using fixed capital formation data to calculate capital services. In accordance with this convention hereby we use the annual capital formation data as investment flows, and divide the non-R\&D fixed assets into three categories: Construction and installation, purchase of equipment and instruments and other expenses, data taken from the calendar year's "China Statistical Yearbook".

For R\&D assets, since China has not established the statistical indicator of R\&D capital formation yet, here we will use the capitalized R\&D internal expenses data instead. According to the explanation of "China Statistical Yearbook on Science and Technology", the R\&D internal expense refers to the real expenditure of surveyed units on their own R\&D activities (basic research, applied research and experimental development) including the direct expenditure on $\mathrm{R} \& \mathrm{D}$ activities, indirect expenditure of management and services on $\mathrm{R} \& \mathrm{D}$ activities, and expenditure on capital construction and material processing by others. The capitalization rates of different types of R\&D expenditures are set according to the previous context. The data for the calculation comes from "China Statistical Yearbook on Science and Technology".

\subsubsection{Price Index}

To eliminate the impact of inflation on capital services, investment data used in the calculations need to be adjusted by the price index to get constant price data. For the study period in this paper (2002 2012), where the price index of 86 sectors are calculated with 2002 as the base year. For the 5 agricultural sectors, the price index is derived from the agricultural production price index in the corresponding period. For the 38 manufacturing sectors, the price index is taken from industrial producer price index by industries in the corresponding period. For the other 43 sectors, the price index is taken from the corresponding period of the fixed assets investment price index.

R\&D price index construction has been a tough problem in the relate studies. Current methods include: a) Set the price index of $R \& D$ expenditure as the weighted average of the price index of non-financial enterprise salary and the implied price index of GNP; b) Set the price index of $R \& D$ expenditure as the weighted average of consumer price index and the price index of fixed assets investment; c) Set the price index of R\&D expenditure as the weighted average of the price index of raw material import and the price index of fixed assets investment. Evidently, there is yet no uniform standard and principle for this issue. This paper employs the second method, setting 0.5 for both the weights of CPI and the price index of fixed assets investment. 


\subsubsection{Base Year's Capital Stock}

For the Equation (2), due to lack of access to investment flows longer than the study period, we have to set the base year's productive capital stock. The capital stock of base year is determined on the assumption that the average growth rate of capital stock equals that of investment, i.e.,

$$
\frac{K_{t}-K_{t-1}}{K_{t-1}}=\frac{I_{t}-I_{t-1}}{I_{t-1}}=v
$$

In Equation (7), $v$ is the average growth rate of investment. When $t=1$, according to $(2)$ and (7), we have

$$
K_{0}=\frac{1+v}{v+\delta} I_{0}
$$

where $\delta$ indicates the decline of the relative efficiency in productive capital stock, calculated by $1-h_{1}$. Thus, we obtain the base year's productive capital stock of different types of assets.

\subsubsection{Service Lives}

Equation (3) requires information on the average service lives of all kinds of assets. According to Fraumeni's estimation ${ }^{[23]}$, the average service life of computer software (including the self-owned and the purchased) is 5 years; that of copyrighted products is 15 years. In China, it is generally held that the average service life of patents is 6 years. This paper holds that the average service lives of the three types of R\&D assets should be included in the mentioned estimation. On this basis, we set the average service life of basic research is 15 years, that of applied research is 8 years, and that of experimental development is 5 years. For the other types of fixed assets, according to the estimation of Sun and Ren ${ }^{[18]}$, we set the average service life of construction and installation as 40 years, that of purchase of equipment and instruments as 15 years and that of other expenses as 20 years.

\subsubsection{Depreciation Rates}

There are four methods in BEA's R\&D satellite account to estimate the depreciation rates: production function method, amortized depreciation models, patent renewal models and market evaluation models. Each of the four methods has its limits. There is a popular solution in empirical research: directly setting the R\&D depreciation rate as $15 \%$, which is taken from experience. Alternatively, this paper obtains the depreciation rates from the age-efficiency profile. In the capital services theory, depreciation rates reflect the decrease in capital value along with the increase of capital service years. The age-price profile and the age-efficiency profile have one-to-one correspondence, i.e.,

$$
\frac{p_{s}^{i}}{p_{0}^{i}}=\frac{\left(h_{s}^{i}+h_{s+1}^{i} /(1+r)+h_{s+2}^{i} /(1+r)+\cdots\right)}{\left(1+h_{1}^{i} /(1+r)+h_{2}^{i} /(1+r)+\cdots\right)}
$$

The ratio of prices with different capital ages on the left side of the equation reflects the depreciation rate. It can be seen that the depreciation rates are described by age-efficiency profile $(h)$ and rate of return $(r)$ from the right side of the equation. Once the age-efficiency profile is determined from Equation (1) and Equation (2), we can endogenously obtain capital depreciation rates, without resorting to extra data. 


\subsection{Empirical Analysis}

According to the method of capital services and the parameters of investment, we calculating sectors' capital services of China during the year from 2002 to 2012. Table 1 and Table 2 are shown the productive capital stock of traditional fixed assets and R\&D in 2012 respectively ${ }^{3}$.

Table 1 The productive capital stock of traditional fixed assets (2012)

Unit: Hundred million yuan

\begin{tabular}{|c|c|c|c|c|c|c|c|}
\hline sector & K1 & $\mathrm{K} 2$ & K3 & sector & K1 & $\mathrm{K} 2$ & K3 \\
\hline agriculture & 4752.5 & 802.2 & 1300.4 & $\begin{array}{l}\text { construction of buildings } \\
\text { and civil engineering }\end{array}$ & 8871.5 & 1279.6 & 1005.8 \\
\hline forestry & 1851.6 & 172.9 & 1734.6 & building installation & 286.3 & 160.5 & 28.5 \\
\hline animal husbandry & 3884.8 & 1057.5 & 1031.4 & $\begin{array}{l}\text { building decoration and } \\
\text { other construction }\end{array}$ & 926.8 & 319.5 & 148.1 \\
\hline fishery & 779.6 & 253.0 & 164.2 & railway transport & 19585.9 & 5534.2 & 5102.2 \\
\hline $\begin{array}{l}\text { services in support of } \\
\text { agriculture, forestry, } \\
\text { animal husbandry and } \\
\text { fishery }\end{array}$ & 4186.9 & 823.1 & 761.9 & road transport & 113512.0 & 4650.0 & 12792.6 \\
\hline $\begin{array}{l}\text { mining and washing of } \\
\text { coal }\end{array}$ & 11657.5 & 6132.4 & 2398.8 & water transport & 7684.5 & 2882.4 & 1170.4 \\
\hline $\begin{array}{l}\text { extraction of petroleum } \\
\text { and natural gas }\end{array}$ & 18015.0 & 2461.6 & 1749.2 & air transport & 2341.9 & 2143.0 & 676.8 \\
\hline $\begin{array}{l}\text { mining and processing of } \\
\text { ferrous metal ores }\end{array}$ & 2867.2 & 1737.2 & 552.2 & transport via pipelines & 692.6 & 239.7 & 114.4 \\
\hline $\begin{array}{l}\text { mining and processing of } \\
\text { non-ferrous metal ores }\end{array}$ & 3016.1 & 1343.7 & 574.4 & $\begin{array}{l}\text { loading, unloading and } \\
\text { other transport services }\end{array}$ & 1108.0 & 346.0 & 198.4 \\
\hline $\begin{array}{l}\text { mining and processing of } \\
\text { nonmetal ores }\end{array}$ & 2170.9 & 1601.3 & 472.8 & storage & 6139.6 & 1376.4 & 1337.2 \\
\hline mining of other ores & 214.8 & 120.5 & 34.6 & post & 236.4 & 68.7 & 24.0 \\
\hline $\begin{array}{l}\text { processing of food from } \\
\text { agricultural products }\end{array}$ & 11111.4 & 6749.8 & 1791.8 & $\begin{array}{l}\text { telecommunications and } \\
\text { other information } \\
\text { transmission services }\end{array}$ & 14335.4 & 8718.0 & 842.4 \\
\hline manufacture of foods & 5731.0 & 3696.5 & 906.7 & computer services & 303.3 & 194.7 & 84.1 \\
\hline manufacture of beverages & 4258.6 & 2811.6 & 739.7 & software & 1075.1 & 312.5 & 223.8 \\
\hline manufacture of tobacco & 626.2 & 577.3 & 156.7 & wholesale trade & 9938.4 & 2238.1 & 2044.6 \\
\hline manufacture of textile & 7254.1 & 6667.9 & 1146.1 & retail trade & 12990.6 & 1931.5 & 2460.8 \\
\hline $\begin{array}{l}\text { manufacture of textile } \\
\text { wearing apparel, } \\
\text { footware and caps }\end{array}$ & 4732.0 & 2680.0 & 773.7 & hotels & 8657.4 & 1033.9 & 1523.7 \\
\hline
\end{tabular}

\footnotetext{
${ }^{3}$ Due to the limited paper length, this paper only shows the productive capital stock in 2012, detailed data in the other years can be obtained from the author if necessary.
} 
Table 1 (Continued) The productive capital stock of traditional fixed assets (2012) Unit: Hundred million yuan

\begin{tabular}{|c|c|c|c|c|c|c|c|}
\hline sector & K1 & $\mathrm{K} 2$ & K3 & sector & K1 & $\mathrm{K} 2$ & K3 \\
\hline $\begin{array}{l}\text { manufacture of leather, } \\
\text { fur, feather and related } \\
\text { products }\end{array}$ & 2276.5 & 1180.8 & 401.0 & catering services & 3473.3 & 714.6 & 578.9 \\
\hline $\begin{array}{l}\text { processing of timber, } \\
\text { manufacture of wood, } \\
\text { bamboo, rattan, and } \\
\text { straw products }\end{array}$ & 3685.4 & 2638.0 & 643.4 & bank & 1034.4 & 516.4 & 207.7 \\
\hline manufacture of furniture & 2709.7 & 1314.2 & 465.7 & security activities & 155.0 & 28.5 & 70.5 \\
\hline $\begin{array}{l}\text { manufacture of paper } \\
\text { and paper products }\end{array}$ & 3986.1 & 3760.6 & 820.7 & insurance & 120.4 & 37.1 & 49.8 \\
\hline $\begin{array}{l}\text { printing, reproduction } \\
\text { of recording media }\end{array}$ & 1971.8 & 1586.1 & 336.3 & other financial activities & 236.8 & 58.7 & 55.6 \\
\hline $\begin{array}{l}\text { manufacture of articles } \\
\text { for culture, education } \\
\text { and sport activities }\end{array}$ & 1245.1 & 682.7 & 185.8 & real estate & 254655.0 & 4460.1 & 87447.8 \\
\hline $\begin{array}{l}\text { processing of petroleum, } \\
\text { coking, processing of } \\
\text { nuclear fuel }\end{array}$ & 6784.6 & 5026.7 & 1329.6 & leasing & 137.7 & 450.3 & 22.7 \\
\hline $\begin{array}{l}\text { manufacture of raw } \\
\text { chemical materials and } \\
\text { chemical products }\end{array}$ & 18563.7 & 16303.4 & 4208.5 & business services & 9263.0 & 933.1 & 2334.6 \\
\hline $\begin{array}{l}\text { manufacture of } \\
\text { medicines }\end{array}$ & 6754.3 & 3871.5 & 1169.4 & $\begin{array}{l}\text { research and } \\
\text { experimental } \\
\text { development }\end{array}$ & 2501.2 & 765.2 & 573.1 \\
\hline $\begin{array}{l}\text { manufacture of chemical } \\
\text { fibers }\end{array}$ & 1205.5 & 1427.6 & 221.3 & $\begin{array}{l}\text { professional technical } \\
\text { services }\end{array}$ & 1504.7 & 440.8 & 310.4 \\
\hline $\begin{array}{l}\text { manufacture of rubber } \\
\text { and plastics }\end{array}$ & 7616.3 & 5998.6 & 1244.1 & $\begin{array}{l}\text { services of science and } \\
\text { technology exchanges } \\
\text { and promotion }\end{array}$ & 1120.0 & 256.6 & 243.1 \\
\hline $\begin{array}{l}\text { manufacture of } \\
\text { non-metallic mineral } \\
\text { products }\end{array}$ & 19398.3 & 14786.6 & 3241.3 & $\begin{array}{l}\text { management of water } \\
\text { conservancy }\end{array}$ & 12996.4 & 537.3 & 2897.3 \\
\hline $\begin{array}{l}\text { smelting and pressing of } \\
\text { ferrous metals }\end{array}$ & 13712.2 & 11432.5 & 1980.3 & $\begin{array}{l}\text { environmental } \\
\text { management }\end{array}$ & 4955.3 & 692.1 & 1166.2 \\
\hline $\begin{array}{l}\text { smelting and pressing of } \\
\text { non-ferrous metals }\end{array}$ & 7787.4 & 6103.1 & 1374.0 & $\begin{array}{l}\text { management of public } \\
\text { facilities }\end{array}$ & 73288.1 & 2561.3 & 21524.6 \\
\hline $\begin{array}{l}\text { manufacture of metal } \\
\text { products }\end{array}$ & 9685.3 & 7017.3 & 1614.0 & services to households & 1799.8 & 262.3 & 286.5 \\
\hline
\end{tabular}


Table 1 (Continued) The productive capital stock of traditional fixed assets (2012) Unit: Hundred million yuan

\begin{tabular}{|c|c|c|c|c|c|c|c|}
\hline sector & K1 & K2 & K3 & sector & K1 & $\mathrm{K} 2$ & K3 \\
\hline $\begin{array}{l}\text { manufacture of general } \\
\text { purpose machinery }\end{array}$ & 13807.0 & 10959.6 & 2301.7 & other services & 1069.0 & 346.8 & 344.4 \\
\hline $\begin{array}{l}\text { manufacture of special } \\
\text { purpose machinery }\end{array}$ & 11858.2 & 7966.2 & 1960.7 & education & 28148.0 & 1625.6 & 2981.8 \\
\hline $\begin{array}{l}\text { manufacture of transport } \\
\text { equipment }\end{array}$ & 15856.9 & 13768.4 & 3316.4 & health & 6914.6 & 1703.6 & 787.0 \\
\hline $\begin{array}{l}\text { manufacture of electrical } \\
\text { machinery and equipment }\end{array}$ & 12326.0 & 9660.8 & 2136.8 & social security & 394.7 & 24.3 & 67.4 \\
\hline $\begin{array}{l}\text { manufacture of } \\
\text { communication } \\
\text { equipment, computers } \\
\text { and other electronic } \\
\text { equipment }\end{array}$ & 9375.9 & 10407.1 & 1694.1 & social welfare & 846.4 & 53.5 & 129.4 \\
\hline $\begin{array}{l}\text { manufacture of measuring } \\
\text { instruments for cultural } \\
\text { activity and office work }\end{array}$ & 2044.6 & 1513.0 & 351.8 & $\begin{array}{l}\text { journalism and } \\
\text { publishing activities }\end{array}$ & 283.8 & 45.9 & 52.0 \\
\hline $\begin{array}{l}\text { manufacture of artwork } \\
\text { and other }\end{array}$ & 3978.4 & 1222.7 & 909.8 & $\begin{array}{l}\text { broadcasting, movies, } \\
\text { television and } \\
\text { audiovisual activities }\end{array}$ & 964.9 & 280.5 & 149.6 \\
\hline $\begin{array}{l}\text { manufacturing recycling } \\
\text { and disposal of waste }\end{array}$ & 862.8 & 520.9 & 171.6 & $\begin{array}{l}\text { cultural and art } \\
\text { activities }\end{array}$ & 4013.3 & 337.3 & 787.1 \\
\hline $\begin{array}{l}\text { production and supply of } \\
\text { electric power and heat } \\
\text { power }\end{array}$ & 45544.3 & 26200.2 & 11720.0 & sports activities & 2301.4 & 148.3 & 443.5 \\
\hline $\begin{array}{l}\text { production and supply of } \\
\text { gas }\end{array}$ & 3468.0 & 1258.0 & 481.2 & entertainment & 3365.6 & 583.4 & 740.1 \\
\hline $\begin{array}{l}\text { production and supply of } \\
\text { water }\end{array}$ & 7616.3 & 1470.8 & 987.2 & $\begin{array}{l}\text { public management } \\
\text { and social organization }\end{array}$ & 27413.4 & 3774.3 & 27639.2 \\
\hline
\end{tabular}

Note: K1 represents the productive capital stock of construction and installation, K2 represents the productive capital stock of purchase of equipment and instruments, K3 represents the productive capital stock of other expenses.

As shown in Table 1, real estate has the highest productive capital stock among the 86 sectors, the amount of which reached 34.66 trillion yuan. While the insurance is lowest, the amount of which is only 20.73 billion yuan. There is a wide disparity between the sectors. In these 86 sectors, except the real estate, only the road transport is more than 10 trillion yuan, less than half of the productive capital stock of real estate. There are 32 sectors whose productive capital stock is between 1 trillion yuan and 10 trillion yuan. There are 42 sectors whose productive capital stock is between 0.1 trillion yuan to 1 trillion yuan, nearly half of sectors 
are in this section. While there are 10 sectors whose productive capital stock is less than 0.1 trillion yuan. The productive capital stock of fixed assets in Table 1 includes construction and installation, purchase of equipment and instruments, other expenses. Real estate is not only ranks first in the total of productive capital stock, its capital stock of construction and installation and other expenses also ranks first, which were 25.47 trillion yuan and 8.74 trillion yuan. While the highest capital stock of purchase of equipment and instruments is the production of electricity and heat supply, which is 2.62 trillion yuan. The insurance has the minimum amount of productive capital stock, its capital stock of construction and installation is also the lowest, only 12.04 billion yuan. The social security has the minimum amount in purchase of equipment and instruments, which is 24.3 billion yuan. While the lowest capital stock of other expenses is the leasing industry, which is only 2.27 billion yuan. At the same time, it shows that different sectors have different distribution on capital stock of construction and installation, purchase of equipment and instruments, other expenses. In most sectors, the construction and installation has the highest capital stock, usually accounting for over $50 \%$ of the total. The construction and installation in road transport accounts for as high as $87 \%$. The capital stock of purchase of equipment and instrument is generally higher than that of other expenses. The capital stock of other expenses usually accounts for less than $20 \%$, while the capital stock of purchase of equipment and instruments is generally between $20 \%$ to $40 \%$. Interestingly, the top three sectors (real estate, road transport and public facilities management) have higher other expenses than their purchase of equipment and instruments. The capital stock of purchase of equipment and instruments in the three sectors account for even less than $5 \%$.

Table 2 The productive capital stock of R\&D (2012) Unit: Hundred million yuan

\begin{tabular}{|c|c|c|c|c|c|c|c|}
\hline sector & K1 & $\mathrm{K} 2$ & K3 & sector & K1 & $\mathrm{K} 2$ & K3 \\
\hline agriculture & 62319.9 & 199350.5 & 570265.9 & $\begin{array}{l}\text { construction of buildings } \\
\text { and civil engineering }\end{array}$ & 299.8 & 5733.9 & 14995.4 \\
\hline forestry & 7253.1 & 26636.5 & 83528.4 & building installation & 0.0 & 0.0 & 2.2 \\
\hline animal husbandry & 6942.1 & 32161.3 & 67143.7 & $\begin{array}{l}\text { building decoration and } \\
\text { other construction }\end{array}$ & 0.0 & 149.0 & 2619.6 \\
\hline fishery & 13733.1 & 30422.2 & 44669.2 & railway transport & 0.6 & 10.6 & 1226.3 \\
\hline $\begin{array}{l}\text { services in support of } \\
\text { agriculture, forestry, } \\
\text { animal husbandry and } \\
\text { fishery }\end{array}$ & 26706.9 & 81101.0 & 170987.3 & road transport & 284.4 & 5272.8 & 48587.2 \\
\hline $\begin{array}{l}\text { mining and washing of } \\
\text { coal }\end{array}$ & 0.6 & 11.1 & 1246.7 & water transport & 110.9 & 335.1 & 6228.5 \\
\hline $\begin{array}{l}\text { extraction of petroleum } \\
\text { and natural gas }\end{array}$ & 42.7 & 0.0 & 0.0 & air transport & 394.4 & 487.2 & 1851.2 \\
\hline
\end{tabular}


Table 2 (Continued) The productive capital stock of R\&D (2012) Unit: Hundred million yuan

\begin{tabular}{|c|c|c|c|c|c|c|c|}
\hline sector & K1 & $\mathrm{K} 2$ & K3 & sector & K1 & K2 & K3 \\
\hline $\begin{array}{l}\text { mining and processing of } \\
\text { ferrous metal ores }\end{array}$ & 0.0 & 0.0 & 0.0 & transport via pipelines & 0.0 & 0.0 & 0.0 \\
\hline $\begin{array}{l}\text { mining and processing of } \\
\text { non-ferrous metal ores }\end{array}$ & 268.2 & 297.9 & 26433.9 & $\begin{array}{l}\text { loading, unloading and } \\
\text { other transport services }\end{array}$ & 0.0 & 22.3 & 0.0 \\
\hline $\begin{array}{l}\text { mining and processing of } \\
\text { nonmetal ores }\end{array}$ & 19.2 & 0.0 & 0.0 & storage & 0.0 & 0.0 & 0.0 \\
\hline mining of other ores & 18.0 & 48.7 & 43.5 & post & 0.0 & 0.0 & 0.0 \\
\hline $\begin{array}{l}\text { processing of food from } \\
\text { agricultural products }\end{array}$ & 783.4 & 4040.0 & 17571.9 & $\begin{array}{l}\text { telecommunications, } \\
\text { information transmission } \\
\text { services }\end{array}$ & 900.5 & 2957.7 & 65835.2 \\
\hline manufacture of foods & 1654.6 & 3055.9 & 3343.5 & computer services & 4612.7 & 24218.2 & 283.0 \\
\hline manufacture of beverages & 10.1 & 330.9 & 732.2 & software & 6771.9 & 45750.4 & 3328.5 \\
\hline manufacture of tobacco & 0.0 & 0.0 & 0.0 & wholesale trade & 0.2 & 0.0 & 169.0 \\
\hline manufacture of textile & 59.3 & 268.6 & 515.2 & retail trade & 0.0 & 0.0 & 92.4 \\
\hline $\begin{array}{l}\text { manufacture of textile } \\
\text { wearing apparel, } \\
\text { footware and caps }\end{array}$ & 0.0 & 47.2 & 74.1 & hotels & 0.0 & 0.0 & 0.0 \\
\hline $\begin{array}{l}\text { manufacture of leather, } \\
\text { fur, feather and related } \\
\text { products }\end{array}$ & 0.0 & 0.0 & 48.6 & catering services & 0.0 & 0.0 & 0.0 \\
\hline $\begin{array}{l}\text { processing of timber, } \\
\text { manufacture of wood, } \\
\text { bamboo, rattan and } \\
\text { straw products }\end{array}$ & 459.8 & 1423.3 & 5380.8 & bank & 0.0 & 180.8 & 0.0 \\
\hline manufacture of furniture & 0.0 & 0.0 & 146.2 & security activities & 0.0 & 0.0 & 0.0 \\
\hline $\begin{array}{l}\text { manufacture of paper } \\
\text { and paper products }\end{array}$ & 0.0 & 0.0 & 476.9 & insurance & 0.0 & 0.0 & 0.0 \\
\hline $\begin{array}{l}\text { printing, reproduction of } \\
\text { recording media }\end{array}$ & 0.0 & 15.7 & 0.0 & other financial activities & 0.0 & 546.1 & 13.6 \\
\hline $\begin{array}{l}\text { manufacture of articles } \\
\text { for culture, education } \\
\text { and sport activities }\end{array}$ & 0.0 & 0.0 & 165.6 & real estate & 0.0 & 0.0 & 0.0 \\
\hline $\begin{array}{l}\text { processing of petroleum, } \\
\text { coking, processing of } \\
\text { nuclear fuel }\end{array}$ & 75.8 & 155.2 & 110.1 & leasing & 0.0 & 0.0 & 0.0 \\
\hline $\begin{array}{l}\text { manufacture of raw } \\
\text { chemical materials and } \\
\text { chemical products }\end{array}$ & \multicolumn{2}{|c|}{37546.741454 .2} & 8574.4 & business services & 0.0 & 373.8 & 304.0 \\
\hline
\end{tabular}


Table 2 (Continued) The productive capital stock of R\&D (2012) Unit: Hundred million yuan

\begin{tabular}{|c|c|c|c|c|c|c|c|}
\hline sector & K1 & $\mathrm{K} 2$ & K3 & sector & K1 & $\mathrm{K} 2$ & K3 \\
\hline $\begin{array}{l}\text { manufacture of } \\
\text { medicines }\end{array}$ & 31417.1 & 65325.7 & 80776.2 & \begin{tabular}{|l} 
exearch and \\
experimental \\
development
\end{tabular} & 2529273.8 & 6412690.7 & 8795886.9 \\
\hline $\begin{array}{l}\text { manufacture of chemical } \\
\text { fibers }\end{array}$ & 0.0 & 0.0 & 632.5 & $\begin{array}{l}\text { professional technical } \\
\text { services }\end{array}$ & 155761.6 & 276472.6 & 393295.9 \\
\hline $\begin{array}{l}\text { manufacture of rubber } \\
\text { and plastics }\end{array}$ & 172.4 & 253.5 & 768.3 & $\begin{array}{l}\text { services of technology } \\
\text { exchanges and promotion }\end{array}$ & 13974.4 & 120848.9 & 29096.5 \\
\hline $\begin{array}{l}\text { manufacture of non- } \\
\text { metallic mineral } \\
\text { products }\end{array}$ & 0.0 & 107.6 & 1983.2 & $\begin{array}{l}\text { management of water } \\
\text { conservancy }\end{array}$ & 7923.3 & 45318.7 & 68343.7 \\
\hline $\begin{array}{l}\text { smelting and pressing of } \\
\text { ferrous metals }\end{array}$ & 0.0 & 41.9 & 411.0 & $\begin{array}{l}\text { environmental } \\
\text { management }\end{array}$ & 19296.5 & 112702.7 & 115543.3 \\
\hline $\begin{array}{l}\text { smelting and pressing of } \\
\text { non-ferrous metals }\end{array}$ & 1.4 & 238.5 & 493.1 & $\begin{array}{l}\text { management of public } \\
\text { facilities }\end{array}$ & 16.2 & 1688.1 & 4311.4 \\
\hline $\begin{array}{l}\text { manufacture of } \\
\text { metal products }\end{array}$ & 32.3 & 64.1 & 383.4 & services to households & 0.6 & 174.7 & 1605.6 \\
\hline $\begin{array}{l}\text { manufacture of general } \\
\text { purpose machinery }\end{array}$ & 0.0 & 184.8 & 6247.7 & other services & 0.0 & 0.0 & 22.2 \\
\hline $\begin{array}{l}\text { manufacture of special } \\
\text { purpose machinery }\end{array}$ & 355.4 & 18094.9 & 76521.6 & |education & 362.0 & 10617.7 & 7391.7 \\
\hline $\begin{array}{l}\text { manufacture of transport } \\
\text { equipment }\end{array}$ & 35247.8 & 76.8 & 445.9 & health & 77109.6 & 246252.2 & 163378.5 \\
\hline $\begin{array}{l}\text { manufacture of electrical } \\
\text { machinery and } \\
\text { equipment }\end{array}$ & 215.3 & 715.3 & 446.9 & social security & 0.0 & 0.0 & 0.0 \\
\hline $\begin{array}{l}\text { manufacture of } \\
\text { communication } \\
\text { equipment and electronic } \\
\text { equipment }\end{array}$ & 13900.8 & 45129.4 & 753.6 & social welfare & 0.0 & 0.0 & 0.0 \\
\hline $\begin{array}{l}\text { manufacture of } \\
\text { measuring instruments } \\
\text { for cultural activity and } \\
\text { office work }\end{array}$ & 193.6 & 5162.4 & 5420.6 & $\begin{array}{l}\text { journalism and } \\
\text { publishing activities }\end{array}$ & 148.4 & 161.1 & 2107.3 \\
\hline $\begin{array}{l}\text { manufacture of artwork } \\
\text { and other }\end{array}$ & 0.0 & 0.0 & 10.5 & $\begin{array}{l}\text { broadcasting, television } \\
\text { and audiovisual activities }\end{array}$ & 0.0 & 0.0 & 1062.2 \\
\hline $\begin{array}{l}\text { manufacturing recycling } \\
\text { and disposal of waste }\end{array}$ & 0.0 & 0.0 & 0.0 & $\begin{array}{l}\text { cultural and art } \\
\text { activities }\end{array}$ & 20549.3 & 10833.5 & 5160.2 \\
\hline $\begin{array}{l}\text { production and supply of } \\
\text { electric power and heat } \\
\text { power }\end{array}$ & 2257.9 & 16919.6 & 24454.9 & sports activities & 237.9 & 4724.1 & 4164.5 \\
\hline $\begin{array}{l}\text { production and supply of } \\
\text { gas }\end{array}$ & 0.0 & 197.3 & 1375.8 & entertainment & 23.7 & 1206.6 & 627.4 \\
\hline $\begin{array}{l}\text { production and supply of } \\
\text { water }\end{array}$ & 10.9 & 0.0 & 0.7 & $\begin{array}{l}\text { public management and } \\
\text { social organization }\end{array}$ & 5682.7 & 42790.6 & 42960.7 \\
\hline
\end{tabular}


In the 86 sectors listed in Table 2, 14 sectors' productive capital stock of R\&D is 0 , which include ferrous metal mining, tobacco, waste material recycling of waste resources processing, pipeline transportation, warehousing, postal services, accommodation, catering, securities, insurance, real estate, leasing, social security and social services.

In the remaining 72 sectors, research and experimental development industry has the highest productive capital stock of $\mathrm{R} \& \mathrm{D}$, the total of which reached 177.379 billion yuan, followed by agriculture, a total of 8.319 billion yuan. The lowest capital stock of R\&D is in construction and installation industry, which is only 0.022 million yuan. Among the 72 sectors, only the research and experimental development's productive capital stock of R\&D more than 100 billion yuan. There are 10 sectors' capital stock of R\&D between 1 billion and 10 billion yuan, 18 sectors' capital stock of R\&D between 0.1 billion yuan and 1 billion yuan, and there are 18 sectors whose capital stock of R\&D is between 10 million yuan and 100 million yuan. While the number of sectors whose capital stock of R\&D less than 10 million yuan is as much as 25 . So it shows that the distribution of productive capital stock of $R \& D$ vary greatly in sectors.

Specifically, productive capital stock of R\&D include three assets: basic research, applied research and experimental development. Research and experimental development not only ranks first in total capital stock of R\&D, its capital stock of basic research, applied research and experimental development are also much higher than the other sectors. The total productive capital stock of R\&D of all the sectors is 220.144 billion yuan in 2012. Among that, the capital stock of experimental development is the highest, which is 109.831 billion yuan, accounting for nearly half of the total; followed by the applied research, which is 79.459 billion yuan; the capital stock of basic research is the lowest, which is 30.854 billion yuan. The research and experimental development industry is very special, no matter the total R\&D capital stock or the three specific activities, it always accounts for over $80 \%$ in all the 86 sectors. As far as the internal structure of sectors is concerned, there is a great difference on the distribution of basic research, applied research and experimental development. Sectors usually have the capital stock of experimental development only, and up to 35 sectors' capital stock of basic research is 0 .
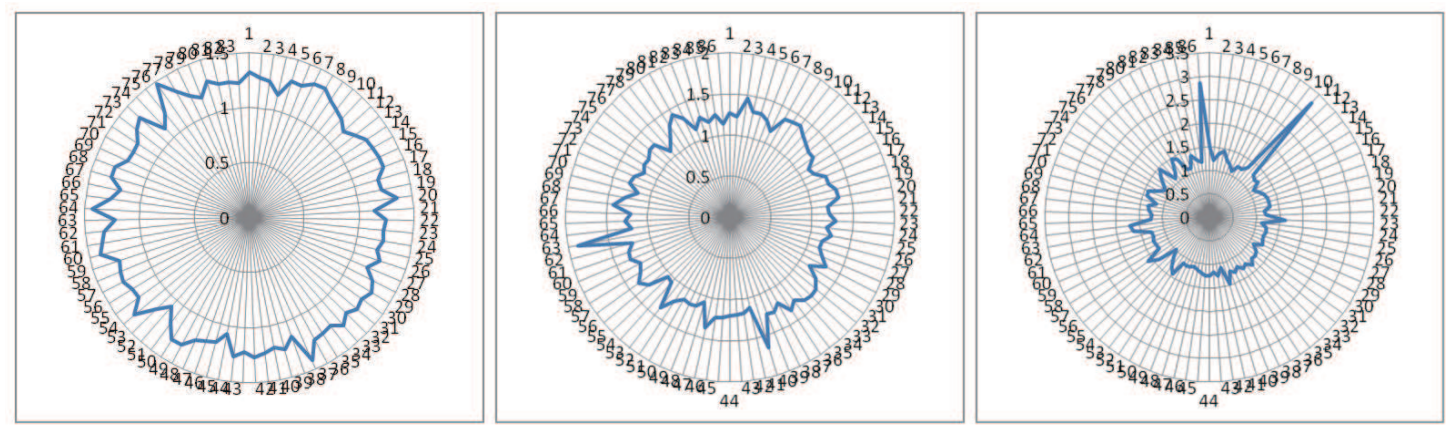

Figure 1 Capital services index of sectors (2004, 2008 and 2012)

Figure 1 shows the changes of the gross capital services index of the six assets in Chinese 86 sectors from 2004 to 2012 . Throughout the study period, there is only one sector, of which the 
gross capital services index has ever been lower than 1 in 2012, that is the telecommunications and other information transmission services. In addition, there are some sectors whose gross capital services index has ever been above 2 in certain years: Securities in 2005, social security in 2009, public management and social organization in 2012, and other mining in 2012. Notably, the capital services index of securities is up to 4.401 in 2005, indicating a dramatic growth of its cash flow in that year.

In different years, the sector that reaches the highest capital services index appears to be different: Social security (1.475) in 2004, securities (4.401) in 2005, leasing (1.707) in 2006, manufacturing recycling and disposal of waste (1.809) in 2007, securities (1.886) in 2008, social security (2.043) in 2009, other services (1.585) in 2010, other financial activities (1.754) in 2011 and other mining (3.259) in 2012. Accordingly, the gross capital services index of telecommunications and other information transmission services has been the lowest among all the sectors from 2005 to 2012, and road transport gets the lowest index in 2004. Overall, the gross capital services index of the 86 sectors mainly fluctuates from 1.26 to 1.32 with not much difference, which demonstrates the capital services remains at a constant level over time.

For the single sector, the index mostly shows irregular fluctuations during the study period, but without tremendous magnitude. Usually the index in sectors fluctuate within a range of 0.5 , and the smallest change of index comes in real estate (0.016). Calculate the geometric mean of the gross capital services index, and it turns out that securities has the highest average capital services index, up to 1.714; telecommunications and other information transmission services scores the lowest, which is 1.039. During the study period every sector's average index is well below 1.5, except for 5 sectors including social security, leasing, securities, manufacturing recycling and disposal of waste, other mining, and these five sectors hit once or twice the highest in the annual capital services index among all sectors.

\section{The Sensitivity Analysis of Capital Services by Sector}

\subsection{The Sensitivity Analysis of Capital Scope}

Endogenous rate of return is developed on the basis of the internal balance of the national accounts, which attribute the profit of all the assets to operating surplus, including unidentifiable productive capital such as natural resources, entrepreneurship and goodwill, etc. Thus it is a precondition that all the assets can be taken into account, that is, no unidentifiable capital exists, when applying endogenous rate of return to computing capital services, or else, the return of capital is destined to be overestimated.

But the observable asset is limited in practice, especially at the level of sector. Even the annual series (at the level of sector) of three traditional fixed assets start from 2002. To mitigate the effect resulted from insufficient in capital accounting on endogenous rate of return, this paper relates to the newly-amended 2008 SNA and categorizes R\&D expenditure into assets accounting to compute its capital service.

From the perspective of computation result, it does not show much influence on the whole capital services for including the R\&D capital. Compared Table 1 with Table 2, the units of quantity is different, one is in hundred million and the other is in ten thousand. The fact that productive R\&D capital stock ( 0.22 thousand billion) accounts for only $0.15 \%$ of the total 
productive capital stock of all sectors (147.89 thousand billion) makes the productive R\&D capital negligible.

Things go the same in most sectors. Among the 86 sectors, the productive R\&D capital stock accounts for less than $0.15 \%$ in 73 sectors. And only in four sectors R\&D capital stock accounts for more than 1\%: Scientific and technological exchanges and promotion service (1.01\%), agriculture (1.21\%), professional technology service (3.66\%), and research, experiment and development (46.2\%). Except for the research, experiment and development, R\&D capital accounts for less than $4 \%$ of the productive capital stock in the other sectors. Moreover, R\&D capital stock of the research, experiment and development industry accounts for only $0.3 \%$ of the gross capital stock of all sectors. It is obvious that R\&D capital is a tiny proportion of productive capital stock.

\subsection{The Sensitivity Analysis of Return Rates}

It is previously mentioned that endogenous rate of return or exogenous rate of return can be used in computing user cost. When analyzing these 86 sectors, this paper refers to the rates of return of corporate bonds and the interest rates of bank medium-term and long-term loans and set the exogenous return on capital as 5\%. Endogenous rates of return are computed according to Equation (1) and Equation (6), with information of each sector's operating surplus and depreciation of fixed assets obtained from 135 sectors' input-output tables of China in 2007. After aggregation and consolidation, we get the endogenous rate of return of 80 sectors.

Table 3 The endogenous rates of return in sectors (2007) Unit: \%

\begin{tabular}{|c|c|c|c|c|c|}
\hline sector & $\mathrm{RR}$ & sector & $\mathrm{RR}$ & sector & $\mathrm{RR}$ \\
\hline agriculture & -9.2 & $\begin{array}{l}\text { manufacture of } \\
\text { non-metallic mineral } \\
\text { products }\end{array}$ & 18.6 & $\begin{array}{l}\text { wholesale trade and } \\
\text { retail trade }\end{array}$ & 67.5 \\
\hline forestry & -0.9 & $\begin{array}{l}\text { smelting and pressing of } \\
\text { ferrous metals }\end{array}$ & 14.1 & hotels & 1.9 \\
\hline animal husbandry & -8.1 & $\begin{array}{l}\text { smelting and pressing of } \\
\text { non-ferrous metals }\end{array}$ & 14.5 & catering services & 178.4 \\
\hline fishery & -6.0 & $\begin{array}{l}\text { manufacture of } \\
\text { metal products }\end{array}$ & 25.1 & $\begin{array}{l}\text { bank, security activities } \\
\text { and other financial } \\
\text { activities }\end{array}$ & 18062 \\
\hline $\begin{array}{l}\text { services of agriculture, } \\
\text { forestry, animal } \\
\text { husbandry and fishery }\end{array}$ & -0.2 & $\begin{array}{l}\text { manufacture of general } \\
\text { purpose machinery }\end{array}$ & 30.2 & insurance & 23.2 \\
\hline $\begin{array}{l}\text { mining and washing of } \\
\text { coal }\end{array}$ & 10.1 & $\begin{array}{l}\text { manufacture of special } \\
\text { purpose machinery }\end{array}$ & 18.5 & real estate & 1.2 \\
\hline $\begin{array}{l}\text { extraction of petroleum } \\
\text { and natural gas }\end{array}$ & 11.3 & $\begin{array}{l}\text { manufacture of } \\
\text { transport equipment }\end{array}$ & 15.7 & leasing & 18.4 \\
\hline
\end{tabular}


Table 3 (Continued) The endogenous rates of return in sectors (2007) Unit: \%

\begin{tabular}{|c|c|c|c|c|c|}
\hline sector & $\mathrm{RR}$ & sector & $\mathrm{RR}$ & sector & $\mathrm{RR}$ \\
\hline $\begin{array}{l}\text { mining and processing } \\
\text { of ferrous metal ores }\end{array}$ & 24.9 & $\begin{array}{l}\text { manufacture of } \\
\text { electrical machinery and } \\
\text { equipment }\end{array}$ & 32.9 & $\begin{array}{l}\text { business services } \\
\text { and tourism }\end{array}$ & 37.5 \\
\hline $\begin{array}{l}\text { mining and processing } \\
\text { of non-ferrous metal } \\
\text { ores }\end{array}$ & 12.9 & $\begin{array}{l}\text { manufacture of } \\
\text { communication } \\
\text { equipment and } \\
\text { computers }\end{array}$ & 28.2 & $\begin{array}{l}\text { research and } \\
\text { experimental } \\
\text { development }\end{array}$ & 5.6 \\
\hline $\begin{array}{l}\text { mining and processing } \\
\text { of nonmetal ores and } \\
\text { other ores }\end{array}$ & 42.6 & $\begin{array}{l}\text { manufacture of } \\
\text { machinery for cultural } \\
\text { activity and office work }\end{array}$ & 31.1 & $\begin{array}{l}\text { professional technical } \\
\text { services }\end{array}$ & 80.5 \\
\hline $\begin{array}{l}\text { processing of food from } \\
\text { agricultural products }\end{array}$ & 12.3 & $\begin{array}{l}\text { manufacture of artwork } \\
\text { and other }\end{array}$ & 17.7 & $\begin{array}{l}\text { services of science and } \\
\text { technology exchanges }\end{array}$ & 26.5 \\
\hline manufacture of foods & 18.2 & $\begin{array}{l}\text { manufacturing recycling } \\
\text { and disposal of waste }\end{array}$ & 1860 & $\begin{array}{l}\text { management of } \\
\text { water conservancy }\end{array}$ & 0.6 \\
\hline $\begin{array}{l}\text { manufacture of } \\
\text { beverages }\end{array}$ & 21.5 & $\begin{array}{l}\text { production and supply } \\
\text { of electric power and } \\
\text { heat power }\end{array}$ & 2.6 & $\begin{array}{l}\text { environmental } \\
\text { management }\end{array}$ & 2.9 \\
\hline manufacture of tobacco & 41.4 & $\begin{array}{l}\text { production and supply } \\
\text { of gas }\end{array}$ & 0.5 & $\begin{array}{l}\text { management of public } \\
\text { facilities }\end{array}$ & 0.3 \\
\hline manufacture of textile & 19.7 & $\begin{array}{l}\text { production and supply } \\
\text { of water }\end{array}$ & 0.0 & services to households & 218.2 \\
\hline $\begin{array}{l}\text { manufacture of textile } \\
\text { wearing apparel, } \\
\text { footware and caps }\end{array}$ & 23.3 & construction & 87.3 & other services & 344.4 \\
\hline $\begin{array}{l}\text { manufacture of leather, } \\
\text { fur, feather and related } \\
\text { products }\end{array}$ & 35.8 & railway transport & 9.6 & education & 3.2 \\
\hline $\begin{array}{l}\text { processing of timber, } \\
\text { bamboo, straw products }\end{array}$ & 26.4 & road transport & 3.0 & health & 17.6 \\
\hline manufacture of furniture & 26.9 & water transport & 22.5 & social security & 15.9 \\
\hline $\begin{array}{l}\text { manufacture of paper } \\
\text { and paper products }\end{array}$ & 14.7 & air transport & 5.4 & social welfare & 15.9 \\
\hline $\begin{array}{l}\text { printing, reproduction } \\
\text { of recording media }\end{array}$ & 16.5 & transport via pipelines & 18.0 & $\begin{array}{l}\text { journalism and } \\
\text { publishing activities }\end{array}$ & 76.4 \\
\hline $\begin{array}{l}\text { manufacture of articles } \\
\text { for culture and sport } \\
\text { activities }\end{array}$ & 30.4 & $\begin{array}{l}\text { loading, unloading and } \\
\text { other transport services }\end{array}$ & 341.5 & $\begin{array}{l}\text { broadcasting, } \\
\text { television, audiovisual } \\
\text { activities }\end{array}$ & 10.1 \\
\hline
\end{tabular}


Table 3 (Continued) The endogenous rates of return in sectors (2007) Unit: \%

\begin{tabular}{|c|c|c|c|c|c|}
\hline sector & $\mathrm{RR}$ & sector & $\mathrm{RR}$ & sector & $\mathrm{RR}$ \\
\hline $\begin{array}{l}\text { processing of petroleum, } \\
\text { coking, nuclear fuel }\end{array}$ & 5.6 & storage & 0.3 & $\begin{array}{l}\text { cultural and art } \\
\text { activities }\end{array}$ & 0.9 \\
\hline $\begin{array}{l}\text { manufacture of raw } \\
\text { chemical materials, } \\
\text { chemical products }\end{array}$ & 13.5 & post & -25.1 & sports activities & 0.0 \\
\hline $\begin{array}{l}\text { manufacture of } \\
\text { medicines }\end{array}$ & 18.4 & $\begin{array}{l}\text { telecommunications } \\
\text { and other information } \\
\text { transmission services }\end{array}$ & 8.3 & entertainment & 16.3 \\
\hline $\begin{array}{l}\text { manufacture of chemical } \\
\text { fibers }\end{array}$ & 19.6 & computer services & 57.3 & $\begin{array}{l}\text { public management and } \\
\text { social organization }\end{array}$ & -0.2 \\
\hline $\begin{array}{l}\text { manufacture of rubber, } \\
\text { plastics }\end{array}$ & 19.3 & software & 37.7 & average & 12.1 \\
\hline
\end{tabular}

Note: RR indicates rates of return.

According to Table 3, the average capital rate of return is $12.11 \%$ in 2007 , higher than the exogenous rate of return which is set to be $5 \%$. Although we have included R\&D expenditure in calculation, it is impossible to cover all the assets that generates profits in production. So the rates of return will undoubtedly be overestimated in some degree. An important drawback of the endogenous rate of return method is the appearance of abnormal values. In the 80 sectors, there are 8 sectors of which the endogenous rate of return appears a negative value. It is generally considered to be caused by changes in short-term price structure, and extending the study period would significantly improve this matter. Since investors can always choose not to invest in certain assets, it is accepted in most research to set the negative rates of return to be 0 .

There are 12 sectors whose endogenous rates of return are less than $5 \%$. These sectors are mainly nonprofit organizations including sports activities, management of public facilities, production and supply of gas, production and supply of electric power and heat power, management of water conservancy, environmental management and education. It is worth mentioning that the endogenous rate of return of the real estate is just $1.15 \%$. Its capital return is very high, but Table 1 shows the productive capital stock of the real estate ranks first in the 86 sectors. This indicates that the abnormal high level of investment accumulation correspondingly pulls down the profitability of capital.

There are 30 sectors whose endogenous rates of return of are between $5 \%$ and $20 \%$, and 17 sectors of which the rates are between $20 \%$ and $40 \%$, most manufacturing sectors included. Abnormally high endogenous rates of return appears in sectors including sectors of bank, security activities and other financial activities, manufacturing recycling and disposal of waste industry, hotels and catering services. Compared with operating surplus and other capital returns, the productive capital stock of these sectors are very low, which is the main reason of the extremely high rates of returns. In addition, the endogenous rate of return of manufacture of tobacco also exceeds $40 \%$, reflecting the characteristics of high profit in monopoly industries. 


\section{Conclusions and Suggestions}

Measuring the contribution of capital input to productivity has always been a hot spot in Macroeconomics. Although capital services have been taken into account of international accounting system as the standard frame of capital measurement, still much need to be done to improve the technical details in practice due to many factors such as the degree of market efficiency and differences in data bases. This paper applied hyperbolic age-efficiency profile to measure the capital input of 86 sectors in China from 2002 2012, with endogenous rate of return and exogenous rate of return respectively, to compute capital service index of 6 fixed assets including $\mathrm{R} \& \mathrm{D}$, and then analyzed the sensitivity of different assets and rates of return. The contribution of this paper can be summed up as three aspects:

First, according to the statistical caliber of the "Frascati Handbook", we demarcate the accounting scope of three R\&D expenses: Basic research, applied research and experimental development. According to the character of R\&D expenditure, we consider that the hyperbolic model is an appropriate choice for the estimation of R\&D's productive efficiency. In the measurement process, we use an age-efficiency profile to deduce an age-price profile and calculate the related depreciation parameters, which, to some extent, would avoid the measurement bias brought by subjective setting. Because estimating capital services is a relatively new research field, this article's conclusions can provide some support for the studies regarding quantifying the contribution of capital to economic growth in China.

Second, productive capital stock, as the radix of capital services, exhibits enormous difference between sectors. With the example of the real estate sector, due to the rapid growth during the study period and its inherent attribute of high level of fixed capital investment, its capital service is much higher than other sectors. For the part of R\&D capital, a large proportion of productive capital stock is distributed in research and experiment development industry. From the dynamic perspective, the capital service index of most sectors fluctuates between 1.26 and 1.32 during the study period. With the only exception of securities industry, the amplitudes of fluctuation of barely go over 0.5 , which implies a stable status of sector capital services.

Finally, because fixed assets is the only factor taken into account, capital's contribution to production is overestimated by the method of endogenous rate of return. Although there is difference in endogenous rate of return between sectors, most are below $20 \%$. On the other hand, the contribution of R\&D capital only accounts for a small proportion and traditional fixed assets have a large share. Therefore, in the moderate range, China should further increase the R\&D capital input, strengthen the protection of intellectual property rights, provide a good policy environment to improve the capability of independent innovation, to provide a lasting impetus to the sustainable and stable development.

In addition, because R\&D statistical work in China started late, certain data in the calculation, such as asset prices and service lives, still have restrictions in application. Therefore, we need to improve the R\&D statistical system further based on the international statistical standards and work to perfect $R \& D$ data by referencing advanced R\&D statistical methods. 


\section{References}

[1] Jorgenson D W. Capital theory and investment behavior. American Economic Review, 1963, 53(2): 247259.

[2] Jorgenson D W, Griliches Z. The explanation of productivity change. Review of Economic Studies, 1967, 34(3): 249-283.

[3] Hall R E, Jorgenson D W. Tax policy and investment behavior. American Economic Review, 1967, 57(3): 391-414.

[4] Hulten C R, Wykoff F C. The estimate of economic depreciation using vintage asset prices. Journal of Econometrics, 1981, 15: 367-396.

[5] Hulten C R, Wykoff F C. The measurement of economic depreciation. Ed. by Hulten C R. Depreciation, Inflation and the Taxation of Income from Capital, The Urban Institute Press, Washington DC, 1981.

[6] United Nations, IMF, et al. System of National Accounts 2008. New York. United Nations, 2009.

[7] OECD. OECD measuring capital manual. http//:www.oecd.org/, 2001.

[8] OECD. OECD measuring productivity manual. http//:www.oecd.org/, 2001.

[9] Oulton N, Srinivasan S. Capital stocks, capital services, and depreciation: An integrated framework. Bank of England Working Paper No. 192, 2003.

[10] Schreyer P. Pierre-emmanuel bignon and julien dupont, OECD capital services estimates: Methodology and a first set of results. OECD statistics Working Paper No. 6, 2003.

[11] Erumban A A, Rental prices, rates of return, capital aggregation and productivity: Evidence from EU and US, CESifo Economic Studies, 2008, 54: 499-533.

[12] Wallis G. Capital Services Growth in the UK: 1950 to 2006. Oxford Bulletin of Economics and Statistics, 2009, 71(6): 799-819.

[13] Inklaar R. The sensitivity of capital services measurement: Measurement all assets and the cost of capital. Review of Income and Wealth, 2010, 56(2): 389-412.

[14] Wu Y B. R\&D stock, knowledge function and productivity. China Economic Quarterly, 2006, 5(3): 11291156.

[15] Wang J. China's manufacturing R\&D capital stock estimates (1998-2005). Statistical Research, 2009, 26(4): $13-18$.

[16] Xiao M, Xie F J. The spatial distribution features of R\&D capital stock in China. Technology Management Research, 2009(8): 435-439.

[17] Wang M X. The estimate on R\&D capital stock of U.S. and its enlightenment to China. Statistical Research, 2011, 28(6): 58-63.

[18] Sun L L, Ren R E. Capital input measurement: A survey. China Economic Quarterly, 2005, 4(4): 823-842.

[19] Sun L L, Ren R E. Estimates of capital stock, capital rental price and capital input index by industries (1981-2000). Journal of Shanxi Finance and Economics University, 2008, 30(4): 96-101.

[20] Cai X C, The capital input measurement of China: 1978-2007. Management World, 2009(11): 11-20.

[21] Cao Y Q, Qin Z Q, Qi Q. Estimating the capital service of China. Statistical Research, 2012, 29(12): 45-52.

[22] Xu X C. An accurate understanding of China's economic statistics. Economic Research Journal, 2010(5): 21-31.

[23] Fraumeni B M. The measurement of depreciation in the U.S. national income and product accounts. Survey of Current Business, 1997.

[24] Australian Bureau of Statistics. Australian national accounts: Concepts, sources and methods. http:// www.abs.gov.au, 2000. 